\title{
Limited foraging flexibility: increased foraging effort by a marine predator does not buffer against scarce prey
}

\author{
Robert A. Ronconi ${ }^{*}$, Alan E. Burger \\ Department of Biology, University of Victoria, PO Box 3020, Stn CSC, Victoria, British Columbia V8W 3N5, Canada
}

\begin{abstract}
Flexibility in activity time budgets allows animals to cope with heterogeneous and changing environments. Many marine predators, such as seabirds, exhibit flexibility in their foraging behaviour to buffer reproductive success against periods of low prey availability. Over 3 years, 2004 to 2006, we studied the foraging behaviour of a threatened seabird, the marbled murrelet Brachyramphus marmoratus in southwestern Vancouver Island, British Columbia, Canada. An information-theoretic approach was used to compare among factors (temporal, spatial, environmental, and competitors) that may influence diving activity. We also quantified local prey availability by hydroacoustic surveys and regional oceanographic conditions (chlorophyll a concentrations and upwelling indices) to investigate relationships between diving activity, food supply and environmental conditions. Prey indices varied spatially, seasonally, and annually, showing reduced prey availability during incubation and chick-rearing of 2005. Upwelling indices and chlorophyll a concentrations, as an index of primary productivity, were delayed in 2005. Year and breeding phase had the greatest impact on diving activity, with additional variation among sites. Murrelets increased diving activity in years and seasons with scarce prey and poor oceanographic conditions (incubation and chick-rearing 2005) and decreased diving activity at sites with high prey availability. There was a linear relationship between diving activity and food availability, suggesting no clear thresholds in response to decreases in prey. Despite their flexible activity budgets, increased foraging effort by murrelets in 2005 was inadequate to ensure average levels of reproductive success. Thus, flexible foraging behaviour by murrelets may be ineffective to buffer reproductive success when environmental conditions are extremely poor.
\end{abstract}

KEY WORDS: Activity budgets · Prey availability · Foraging ecology · Thresholds · Seabirds · Brachyramphus marmoratus

Resale or republication not permitted without written consent of the publisher

\section{INTRODUCTION}

The ability of animals to adjust activity budgets affords several advantages to their survival and reproduction. In the marine environment, where food resources are often patchy and ephemeral, flexible activity budgets can allow predators to cope with fluctuations in prey availability (Mori \& Boyd 2004). Although some life-history traits, such as number of offspring, may be relatively unchangeable in the face of short-term environmental perturbations, others, like foraging behaviour, appear comparatively flexible.
This is particularly true for many seabirds that have several fixed life-history traits (e.g. clutch sizes, delayed age of maturity; Gaston 2004) but flexible foraging behaviours that are adaptable to variable environmental conditions (Waugh \& Weimerskirch 2003).

Flexibility in foraging behaviour has been demonstrated widely in seabirds, and in particular piscivorous alcids (Alcidae), that adjust their activity budgets, spending more time foraging in years when foraging conditions are poor (Burger \& Piatt 1990, Uttley et al. 1994, Litzow \& Piatt 2003). Behavioural responses to 
prey may be observed much earlier than physiological or reproductive responses (Piatt et al. 2007), yet despite the apparent flexibility of activity budgets for many seabirds, thresholds may exist whereby foraging flexibility can no longer buffer reproductive success against very low food availability (Dall \& Boyd 2002). Cairns (1987) predicted that seabirds would exhibit non-linear, threshold-type responses to changes in prey availability, whereby small changes in prey trigger rapid changes in adult survivorship, reproductive performance, and/or foraging effort. Marine predators typically show such non-linear, threshold responses to prey availability (Reid et al. 2005, Harding et al. 2007, Piatt et al. 2007).

Studying the behavioural responses of predators to prey availability is important for understanding limiting factors in marine ecosystems and has important conservation and management implications. Identifying prey thresholds (Harding et al. 2007, Piatt et al. 2007) can identify the causes of reproductive success (or failures) which have important implications for population monitoring in long-lived animals. Moreover, establishing clear linkages between predators and prey can have important implications for monitoring fish populations by using seabirds as indicators (Cairns 1987, Piatt et al. 2007). Though many studies have linked seabird foraging behaviour to prey availability (Burger \& Piatt 1990, Uttley et al. 1994, Litzow \& Piatt 2003, Harding et al. 2007, Piatt et al. 2007), few integrative studies exist combining oceanography, prey availability, and breeding success in relation to foraging ecology.

Marbled murrelets Brachyramphus marmoratus are non-colonial seabirds with cryptic nests on limbs of old-growth conifers (Nelson 1997). They have been afforded threatened or endangered status throughout much of their range due to loss of inland nesting habitat (Burger 2002), and recent findings have suggested that variability and changes in marine habitat are also influencing their decline and recovery. Their reproductive success has been linked to the availability of prey (Peery et al. 2004, Becker et al. 2007) and longterm dietary shifts (Becker \& Beissinger 2006, Norris et al. 2007). Adult survival has been linked to large-scale oceanographic conditions; survival increased in warmwater years (Peery et al. 2006). In British Columbia, Canada, annual adult survival rates are quite high (range 0.829 to 0.929 , Cam et al. 2003); thus, low reproductive rates (0.16 to 0.23 female offspring female adult $^{-1} \mathrm{yr}^{-1}$, Burger 2002, Bradley et al. 2004) are likely contributing to population declines.

The role of behavioural flexibility by marbled murrelets to buffer variations in foraging conditions is unknown, but is likely to be important in understanding the long-term responses of this species, and marine predators in general, to changing oceans. We studied the foraging behaviour of marbled murrelets in southwestern British Columbia during 3 years, 2004 to 2006, with contrasting prey availability. In 2005, coastal regions of the northeastern Pacific experienced highly anomalous conditions with the onset of upwelling delayed by 2 to 3 mo (Schwing et al. 2006), which resulted in widespread ecosystem changes affecting many organisms and unprecedented reproductive failure in some seabirds (Sydeman et al. 2006).

We used an information-theoretic approach (Burnham \& Anderson 2002) to distinguish between factors that may be influencing diving activity of marbled murrelets. We compared models with (1) temporal predictors (time-of-day, breeding phase, year), (2) spatial predictors (multiple sites), (3) environmental predictors (tide, sea state, cloud cover), and (4) inter- and intraspecific interactions (densities of murrelets and competitors). We quantified local prey availability and regional oceanographic conditions (chlorophyll a [chl a] concentrations and upwelling indices) to investigate relationships between diving activity and food supply, and tested the shape of this relationship to examine threshold effects predicted by Cairns (1987). Finally, we examined indices of reproductive success to determine if foraging flexibility enabled murrelets to safeguard reproductive success against periods of poor prey availability.

\section{MATERIALS AND METHODS}

From 2004 to 2006 we studied the foraging behaviour of marbled murrelets during the breeding season (mid-May to early August) along the West Coast Trail unit of Pacific Rim National Park Reserve on Vancouver Island, British Columbia (Fig. 1). This $65 \mathrm{~km}$ stretch of coast is exposed to the Pacific Ocean with adjacent inland areas that include large tracts of old-growth forest which are nesting habitat for marbled murrelets. Boat-based prey measurements and land-based foraging behaviour observations were made from 12 sites along this area. During the breeding season, murrelets are effectively studied by land-based observations because they typically forage in shallow water within $2 \mathrm{~km}$ from shore (Burger 2002) on small schooling fish such as sand lance Ammodytes hexapterus and herring Clupea harengus.

Sampling design simultaneously considered the interactions between murrelet diving activity (as a proxy for foraging effort), prey availability, regional oceanographic conditions and the resultant effects on murrelet reproductive success. Table 1 summarizes the data collected and analyzed for this study. Collection of prey data were limited due to equipment failure, but 


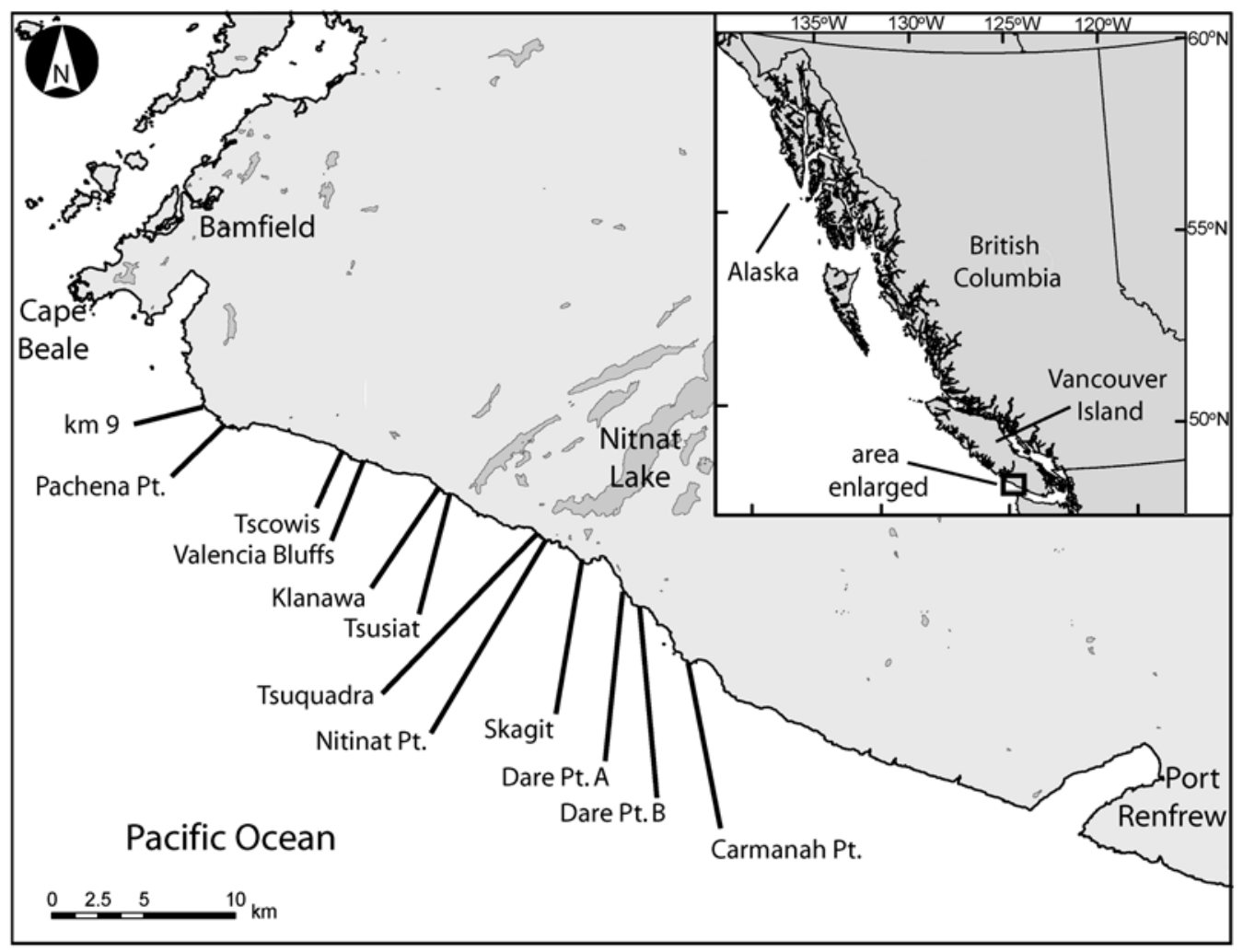

Fig. 1. Study area located along the southwest coast of Vancouver Island, BC, Canada. Land-based telescope observations and boat-based hydroacoustic surveys were conducted at each of the 12 observation sites

those data that were collected measured prey at Carmanah Bay in 2 years (allowing for interannual and seasonal comparison) and prey was measured at multiple sites in 2005 (allowing for spatial comparison). See 'Discussion' for limitations of this sampling design.

Diving activity. Observations of murrelet diving activity were made from 12 cliff-top observations sites (Fig. 1) using 20× magnification telescopes. The observer was between $\sim 10$ to $30 \mathrm{~m}$ from the water's edge depending on the site. Each site was surveyed 2 to 5 times in 2004. In 2005 and 2006, one site (Carmanah Bay) was surveyed 5 to $8 \mathrm{~d}$ each year while other sites were surveyed 1 or $2 \mathrm{~d}$ each year. This uneven sampling design means that observations at Carmanah contribute to the bulk of the dataset; however, this is controlled for by inclusion of site as a random variable in the analysis.

Instantaneous scan sampling techniques (Davoren \& Burger 1999) were used to record murrelet behaviours. A series of scans consisted of twenty 1 min scans over each hour of observation. During each $1 \mathrm{~min}$ interval, the scope was fixed and we recorded the numbers of birds (murrelets and other seabird species), group sizes, and activity state of individuals on the water (resting or diving) within the field of view of the scope. This was repeated for 20 non-overlapping fields of view. The $60 \mathrm{~s}$ observa-

Table 1. Brachyramphus marmoratus. Summary of data collected for analyses investigating interactions between diving activity (hours used in analysis after controlling for autocorrelation), prey availability, oceanographic conditions (weeks selected that coincided with observation periods of diving activity), and reproductive success. Reproductive success was measured by observations of hatch-year murrelets observed during diving activity observations. na = not applicable, because reproductive success could not be measured during the incubation period

\begin{tabular}{|clcccc|}
\hline \multirow{2}{*}{ Year } & \multirow{2}{*}{ Period } & \multicolumn{5}{c}{\begin{tabular}{c} 
Parameters measured in the study \\
\cline { 3 - 6 }
\end{tabular}} & & $\begin{array}{c}\text { Diving activity } \\
\text { (h of obs.) }\end{array}$ & $\begin{array}{c}\text { Prey (no. of } \\
\text { surveys) }\end{array}$ & $\begin{array}{c}\text { Oceanographic } \\
\text { data (no. of wk) }\end{array}$ & $\begin{array}{c}\text { Reproductive } \\
\text { success }\end{array}$ \\
\hline 2004 & Incubation & 114 & 0 & 3 & na \\
& Chick-rearing & 71 & 6 & 4 & Yes \\
& Post-fledging & 51 & 2 & 4 & Yes \\
2005 & Incubation & 27 & 13 & 3 & Yes \\
& Chick-rearing & 37 & 20 & 4 & Yes \\
2006 & Post-fledging & 10 & 10 & 4 & Yes \\
& Incubation & 14 & 0 & 3 & Yes \\
& Chick-rearing & 90 & 0 & 4 & \\
& Post-fledging & 36 & 0 & 4 & \\
\hline
\end{tabular}


tion interval was chosen to document all diving individuals given the average dive ( 25 s) and surface ( 20 s) times for murrelets (Jodice \& Collopy 1999). Proportion of birds diving is used as a proxy for foraging effort (details in subsection 'Data selection, observer reliability, and temporal autocorrelation'). Hourly surveys were conducted from dawn until dusk at 3 sites (Carmanah, Pachena, Tsusiat) and the first $4 \mathrm{~h}$ after sunrise and last $3 \mathrm{~h}$ before sunset at other sites. All observations were made in conditions with Beaufort sea state $<3$.

We recorded murrelet age-class in all scans. Newly fledged murrelets (hatch-year; HY) can easily be distinguished from after-hatch year (AHY) birds based on plumage differences, and ratios of HY to AHY birds may be used as indices of murrelet reproductive success (Kuletz \& Kendall 1998). We compared HY and AHY densities and HY:AHY ratios to examine intraand inter-annual variation in murrelet demographics.

All observations were categorized into 3 breeding phases: incubation, chick-rearing and post-fledging periods. Based on average known laying dates for Vancouver Island (McFarlane Tranquilla et al. 2005) and known incubation and fledging duration (Nelson 1997), we categorized peaks in nesting chronology as incubation (15 May to 7 June), chick-rearing (8 June to 15 July) and post-fledging (16 July to 8 August).

Indices of prey, primary productivity, and upwelling. To assess relative abundance of prey (schooling fish or euphausiids) among years, seasons and sites, hydroacoustic surveys were conducted by boat transects in waters visible from the shore-based observation points. A paper-recording $200 \mathrm{kHz}$ echosounder (Furuno FE606) was used from a $5 \mathrm{~m}$ rigid-hull inflatable boat traveling at $10 \mathrm{~km} \mathrm{~h}^{-1}$ to measure relative prey abundance (Piatt 1990). Transect lines $500 \mathrm{~m}$ apart were perpendicular to shore from the 5 to $30 \mathrm{~m}$ depth contours, approximately $100 \mathrm{~m}$ to $1.5 \mathrm{~km}$ from shore. At Carmanah Bay, 13.4 linear $\mathrm{km}$ of transects were surveyed in 2004 ( $\mathrm{N}=8$ surveys) and 2005 ( $\mathrm{N}=6$ surveys). The other 11 sites had 2 to $7 \mathrm{~km}$ of transects surveyed 3 to 4 times each in 2005. Hydroacoustic surveys were not conducted in 2006 due to equipment failure.

We quantified prey along transects by measuring echo-signal intensity on the paper echosounder output (Piatt 1990). Signal intensity was scored based on percentage cover ( 0 to 9 ) within blocks partitioned by time (1 min intervals; approx. $160 \mathrm{~m}$ of travel) and depth (5 m intervals). Scores were squared to better estimate prey abundance (Piatt 1990). Three indices of prey were quantified to describe prey availability for each survey at each site: (1) abundance index (sum of scores in each depth block for each minute; averaged for each survey), (2) prey concentration index (mean score of non-zero blocks; averaged for each survey) to indicate different prey concentrations despite similar abun- dance estimates and (3) Green's index of dispersion (Ludwig \& Reynolds 1988) calculated by $\left[\left(\mathrm{s}^{2} / \bar{x}\right)-1\right] /$ (n -1$)$ where $\bar{x}=$ mean abundance, $s^{2}=$ variance of abundance and $\mathrm{n}=$ number of 1 min segments. Abundance indicates the quantity of prey, concentration indicates the density of prey where it occurs, and Green's index indicates the distribution of prey throughout the survey area.

To test the shape of the relationship between prey availability on diving activity, we plotted the mean proportion of birds diving (for each of 10 survey $d$ at Carmanah) with respect to the most recent prey estimate (usually from a hydroacoustic survey made within $1 \mathrm{~d}_{\text {; }}$ mean $\pm \mathrm{SE}$, $2.0 \pm 0.4 \mathrm{~d}$; range, 1 to $4 \mathrm{~d}$ ). Five hydroacoustic surveys at Carmanah were omitted from this test because the most recent observations of diving activity were greater than $6 \mathrm{~d}$ apart. To examine relationships among sites, we calculated the mean proportion of birds diving for each site in 2005. These means were paired with mean prey abundance, concentration and Green's index for each site.

We assessed regional indices of primary productivity (chl a) and upwelling. Weekly composite chl a data were downloaded from Sea-viewing Wide Field-of-view Sensor (SeaWiFS) satellite images (http://oceancolor.gsfc. nasa.gov/) for the period of study in each year. Images were obtained as compressed hierarchical data format (.hdf) files which were unzipped and the .hdf extension was added to each file. Files were opened using HDF Viewer 2.3 (HDF Group, http://hdf.ncsa.uiuc.edu/) and values were extracted from the region surrounding the study area and pasted in a spreadsheet for further analysis. SeaWiFS images provide chl a concentrations in mg $\mathrm{m}^{-3}$ at a resolution of $9 \times 9 \mathrm{~km}$ pixels. For each week, we determined a mean regional chlorophyll concentration by averaging pixel values along the study area coastline up to 2 pixels $(18 \mathrm{~km}$ ) from shore (total $\mathrm{N}=828$ pixels; 26 pixels $\mathrm{wk}^{-1}$ minus those obscured by cloud cover, average 1 pixel excluded due to cloud cover, maximum 15 pixels excluded). The overall mean \pm SE chlorophyll level was $4.13 \pm 0.26 \mathrm{mg} \mathrm{m}^{-3}$. We used ANOVA to compare chlorophyll levels among years within each breeding phase using individual pixels as the unit of analysis.

Upwelling indices (www.pfeg.noaa.gov/products/ PFEL/modeled/indices/) were obtained from the location nearest to our study area $\left(48^{\circ} \mathrm{N}, 125^{\circ} \mathrm{W} ; \sim 68 \mathrm{~km}\right.$ away). We included daily upwelling indices $\left(\mathrm{m}^{3} \mathrm{~s}^{-1}\right.$. $100 \mathrm{~m}^{-1}$ coastline) which overlapped temporally with chlorophyll images $(\mathrm{N}=88 \mathrm{~d}$ each year; 16 May to 11 August). We averaged daily upwelling indices for each week (overall mean \pm SE upwelling index was $21.6 \pm 2.7$ ). ANOVA was used to compare upwelling among years within each breeding phase using individual days as the unit of analysis. 
Data selection, observer reliability, and temporal autocorrelation. Proportions of birds diving (relative to the total number of birds observed on the water) were calculated for each hour of observation. Proportions may be sensitive to low numbers of birds observed (e.g. 1 individual diving means 100\% diving); therefore, we included only hourly scans with $\geq 5$ individuals on the water. Mean \pm SE number of murrelets observed was $39.1 \pm 1.6 \mathrm{~h}^{-1}$.

During 3 years, 6 observers conducted spotting scope observations with 1 observer (R.A.R.) observing in all years. We compared inter-observer reliability by testing differences among observers (Mann-Whitney $U$ and Kruskal-Wallis tests dependent on the number of observers in each year) in measures of proportion diving and bird densities (birds per 1 min scan). Observer comparisons were grouped by 3 time blocks (incubation, chick-rearing and post-fledging) in each year. There were no significant inter-observer differences in bird density estimates during any time block of any year. Estimates of percent diving showed significant inter-observer differences in only 2 of 9 time blocks (chick-rearing 2006, p = 0.047; post-fledging 2005, $p=0.031$ ). Thus, there was no observer bias in the numbers of birds observed, and occasional, though not systemic, reliability issues for proportion diving estimates. We retained all data to maximize sample size.

Data were collected in consecutive hours; therefore, proportions of birds diving may be autocorrelated between adjacent hours. Traditional autocorrelation analyses could not be applied because data were collected in short ( 3 to $4 \mathrm{~h}$ ) non-consecutive time blocks. We used a modified autocorrelation analysis which lagged hours by sequentially shifting time series by 1 , 2, 3 h, etc. (max. $14 \mathrm{~h}$ ), and calculating Pearson's correlation coefficients for each shift. Significance of correlations was determined at $\mathrm{p}<0.05$.

Diving activity analysis and modeling. Proportion of birds diving in each hour was the dependent variable in all analyses. Hourly observations were categorized by tide phase, time of day, breeding phase (described in subsection 'Diving activity'), bird densities, year, and site. Time of day was discriminated by chick- vs. selffeeding periods (dawn/ dusk vs. other daytime hours). Murrelets feed their chicks at all times of the day though the majority of feedings occur near dawn and dusk; up to $60 \mathrm{~min}$ after sunrise, and after $90 \mathrm{~min}$ before sunset (Burger 1997). We were only able to conduct observations during daylight hours; therefore, we considered primary chick-feeding periods as the first $h$ after sunrise and the last $2 \mathrm{~h}$ before sunset. To test whether the presence/ absence of conspecifics and other seabird species influenced the diving activity of murrelets, we calculated densities (number of birds divided by number of $1 \mathrm{~min}$ scans) of murrelets and common murres Uria aalge, the
2 most common diving piscivores and possible competitors (Burger et al. 2008), for each observation hour.

We modeled the response variable (proportion of birds diving) using generalized linear models (McCullagh \& Nelder 1989) in SPSS 15.0. Proportional data were modeled with a binomial distribution and logit link function. Overdispersion, which is common with proportional data in binomial models and can lead to underestimates of standard error, was corrected with the addition of a dispersion parameter $\varnothing$ that is equal to Pearson $\chi^{2} / \mathrm{df}$ estimated from the global model (Vieira et al. 2000). In our global model, Pearson $\chi^{2} / \mathrm{df}=4.346$, suggesting overdispersed data; therefore, 4.346 was used as an estimate of $\varnothing$ in all models and $\hat{\mathrm{C}}$ for quasi-likelihood adjusted Akaike's information criteria $\left(\mathrm{QAIC}_{\mathrm{c}}\right)$ calculations.

An information-theoretic approach with AIC scores was used to rank alternative candidate models, including a global model (all possible parameters) and a null model (intercept only) to assess model fit (Burnham \& Anderson 2002). We used quasi-likelihood adjustments and corrections for small sample size $\left(\mathrm{QAIC}_{\mathrm{c}}\right)$ to rank candidate models, with $\hat{\mathrm{C}}=4.346$ as the variance inflation factor, to account for overdispersion (Burnham \& Anderson 2002). The parameter count $(k)$ for each model included all estimable parameters: $+1 k$ for an intercept,$+1 k$ for the dispersion parameter,$+1 k$ for each covariate, and $+(\mathrm{N}-1) k$ for each categorical variable, where $\mathrm{N}=$ number of categories. A parameter count of $k=1$ was given to the categorical variable Site which was treated as a random effect variable.

We modeled the effect of several covariates and fixed factors on the response variable. Covariates included marbled murrelet density (MM_dens), common murre density (CM_dens) and percent cloud cover (CC) in 10ths. The following categorical predictor variables were included in models: Year $(2004,2005,2006)$, Phase (incubation, chick-rearing, post-fledging), Timeof-Day (dawn, daytime, dusk), Site, Tide phase (high \pm $1.5 \mathrm{~h}$, ebb, low $\pm 1.5 \mathrm{~h}$, flood) and Beaufort sea state $(0,1,2,3)$. Candidate models were selected a priori from combinations of potential factors, and included biologically plausible interactions. Candidate models were developed in 4 categories (with candidate variables in parentheses): (1) Temporal (Year, Phase, Timeof-Day), (2) Spatial (Site), (3) Inter- and Intra-specific interactions (murrelet density index, common murre density index) and (4) Environmental (Tide phase, Sea State, CC). Candidate models were ranked across model categories using QAIC $_{\mathrm{C}}$ scores and multi-model averaging was used to determine parameter likelihoods to test the weight of individual parameters. Finally, to assess interaction between models in the 4 categories, we then added each factor independently to a model containing the parameters with the highest parameter likelihoods (i.e. best model + other parameters). 


\section{RESULTS}

\section{Prey, primary productivity, upwelling}

Hydroacoustic measures of prey abundance, concentration and dispersion varied both annually and seasonally (Table 2). In Carmanah Bay there was a trend towards higher prey concentrations in 2004 than in $2005\left(t_{12}=1.765, \mathrm{p}=0.103\right)$. Seasonally, prey concentrations varied significantly in both $2004\left(t_{6}=2.407\right.$, $\mathrm{p}=0.053$ ) and 2005 (ANOVA: $F_{2,40}=3.867, \mathrm{p}=0.029$ ). Prey concentrations were higher during chick-rearing than post-fledging in 2004, but were higher during post-fledging than during incubation or chick-rearing in 2005 (Table 2). Similar seasonal and annual trends in prey abundance and dispersal (Green's index) were apparent; prey was more abundant and clumped early in 2004 but later in 2005. In summary we saw higher prey availability for murrelets early in the 2004 season but late in 2005 .

Regionally, there were strong differences in primary productivity and upwelling indices among years within each of the 3 nesting phases (Fig. 2). During the incubation period, chlorophyll concentrations were significantly lower in 2005 (ANOVA: $F_{2,229}=11.238$, p < 0.001; Tukey's post hoc: $2005<2004$, p < 0.001, $2005<2006, \mathrm{p}=0.009$ ) and upwelling indices were lower in 2005 than in $2004\left(F_{2,69}=2.998, \mathrm{p}=0.056\right)$. During chick-rearing, chlorophyll concentrations were lower in 2005 than $2004\left(F_{2,284}=3.710, \mathrm{p}=0.026\right)$ and upwelling was lower in 2005 than $2006\left(F_{2,93}=7.278\right.$, $\mathrm{p}=0.001)$. During post-fledging periods the pattern was reversed and 2005 showed higher chlorophyll con- centrations $\left(F_{2,306}=4.603, \mathrm{p}=0.011 ; 2005>2004, \mathrm{p}=\right.$ $0.015,2005>2006, \mathrm{p}=0.045)$ and upwelling indices $\left(F_{2,93}=5.942, \mathrm{p}=0.004 ; 2005>2004, \mathrm{p}=0.009,2006>\right.$ 2004, $\mathrm{p}=0.012$ ). Overall this illustrates a pattern of delayed upwelling and primary productivity in our study area in 2005.

\section{Murrelet diving activity}

Over 3 yr we recorded observations on 25391 sightings of individual murrelets during $765 \mathrm{~h}$ of observations. Data were insufficient $(<5$ birds $)$ for proportion diving to be calculated in $131 \mathrm{~h}$. General patterns in diel diving activity showed increased foraging near dawn and dusk (Fig. 3), supporting categorization of Time-of-Day variable (see 'Materials and methods') for the main models. Temporal autocorrelation in murrelet diving activity was apparent but was not consistent across years or breeding phases. Proportions of birds diving were correlated at 1 and $2 \mathrm{~h}$ time lags in 2005 (incubation and chickrearing), a $1 \mathrm{~h}$ lag during chick-rearing in 2004, and not at all in 2006. To remove autocorrelation, we subsampled hourly observations from periods containing autocorrelation by systematically removing alternate hours (periods with $1 \mathrm{~h}$ lagged correlations) and 2 out of 3 consecutive h (periods with 2 h lags), thus removing $153 \mathrm{~h}$ of observation. The remaining 481 independent $\mathrm{h}$ of observation were used in generalized linear models.

We tested models across 4 broad categories including Temporal, Spatial, Environmental, and Inter- and Intra-specific Interactions. Model ranking showed substantial support $\left(\Delta \mathrm{AIC}_{\mathrm{C}} \leq 2\right)$ for 2 temporal models (Year and Year*Phase interaction), less support for other temporal models and the spatial model, and essentially no support $\left(\Delta \mathrm{AIC}_{\mathrm{c}}>10\right)$ for the null model, most of the environmental models, and the inter-/ intra-specifics models (Table 3). Parameter likelihoods (sum of weight $\left[\mathrm{w}_{i}\right]$ for each parameter from alternative models; Burnham \& Anderson 2002) suggests that Year (0.56) and Year*Phase (0.28) were the parameters with the most support. Site had a parameter likelihood of 0.05 and several other temporal parameters had likelihoods of about 0.10 (Phase, TimeDay, Year*TimeDay). Evidence ratios suggest potential model 
uncertainty between the top 2 models: the Year model $\left(w_{i}=0.40\right)$ was only twice as likely as the Year*Phase model $\left(w_{j}=0.20\right.$, where $w_{j}$ is the model weight of the comparison model) to be the best model (evidence ratio $w_{i}: w_{j}=2$ ). Thus, both Year and the Year*Phase interaction appear to be the strongest parameters predicting murrelet diving effort.

Given that non-temporal variables may interact with the temporal models, we tested the improvement in model fit by adding independent variables to the best temporal model (Table 4). We considered the best temporal model to be that with Year and Year*Phase because these were the most likely parameters (this section). The best temporal model was improved only with the addition of the Site variable with little evidence of competing models ( $w_{i}=$ 0.84). Thus, there is strong evidence that variation in murrelet diving activity is determined primarily by temporal patterns (Year, Year*Phase; Fig. 4a) and secondarily by spatial patterns (Site effects; Fig. 4b). Overall, we observed higher diving activity in 2005, particularly during incubation and chick rearing.

\section{Predator-prey associations}

Correlations between prey indices and murrelet activity levels suggest that murrelet diving activity was affected by prey availability (Fig. 5). Within one study site (Carmanah Bay) that was surveyed multiple times in 2004 and 2005, diving activity showed no correlation with prey abundance index $\left(\mathrm{r}^{2}=0.007, \mathrm{~N}=10, \mathrm{p}=0.821\right.$; Fig. 5a) or Green's index of dispersion $\left(\mathrm{r}^{2}=0.045\right.$, $\mathrm{N}=10, \mathrm{p}=0.556$; Fig. $5 \mathrm{c}$ ) but showed a weak trend towards decreasing activity with increasing prey concentration index $\left(r^{2}=0.244, N=10, p=0.147\right.$; Fig. 5b). Lack of fit may have resulted due to a mismatch in timing of prey surveys with timing of foraging behaviour observations (6 prey surveys were $\pm 1 \mathrm{~d}$ before/ after foraging estimate, 2 surveys $\pm 3 \mathrm{~d}$, and 2 surveys $\pm 4 \mathrm{~d}$ ). Among 12 sites surveyed in 2005, the proportion of murrelets diving was negatively correlated with prey abundance $\left(\mathrm{r}^{2}=0.494\right.$, $\mathrm{N}=12, \mathrm{p}=0.011$; Fig. $5 \mathrm{~d})$, prey concentration $\left(\mathrm{r}^{2}=0.418, \mathrm{~N}=12, \mathrm{p}=0.023\right.$; Fig. 5e)
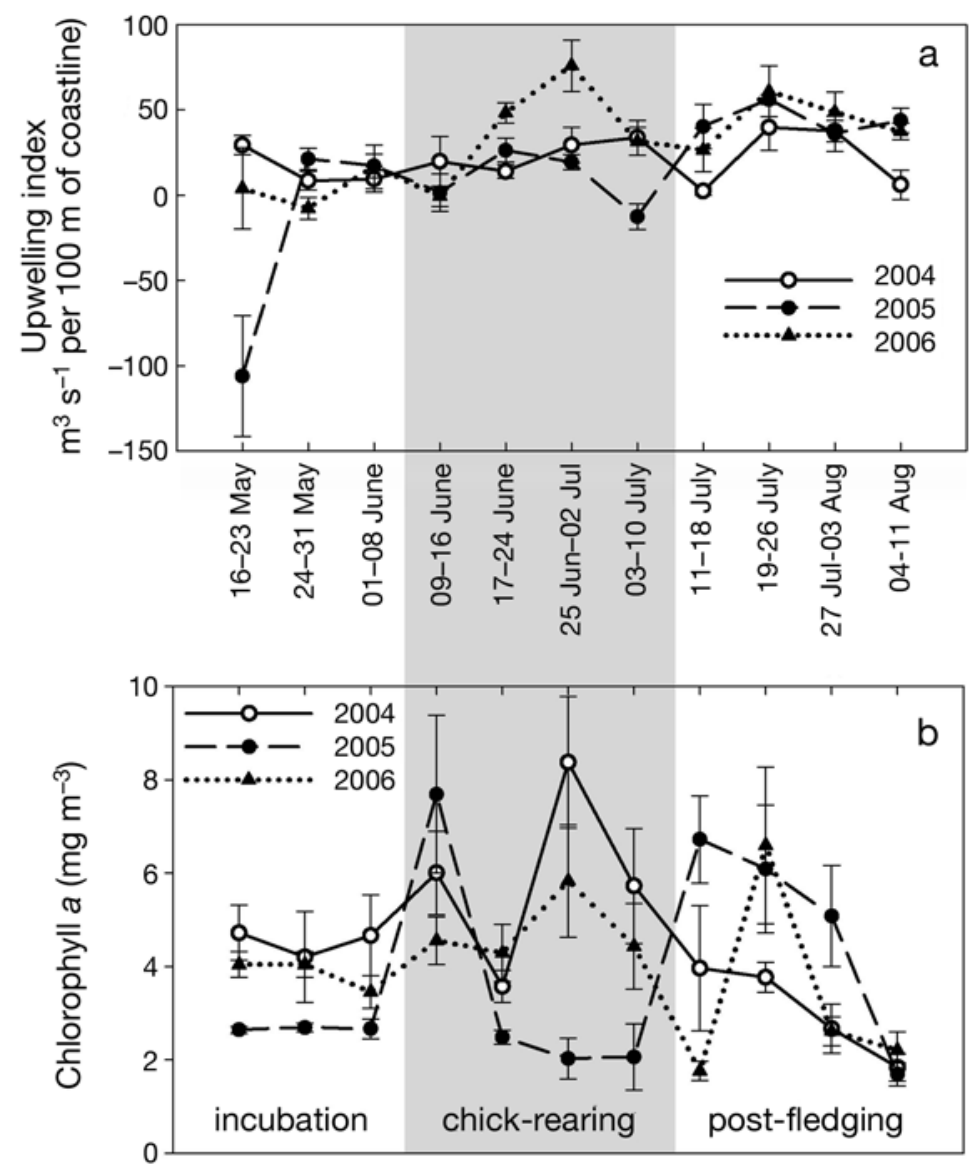

Fig. 2. Regional weekly indices (mean \pm SE) of (a) upwelling and (b) chlorophyll a concentrations during the study period. Chlorophyll concentrations were obtained from Sea-viewing Wide Fieldof-view Sensor (SeaWiFS) satellite images within $18 \mathrm{~km}$ of the study area. Upwelling indices were obtained from NOAA on-line data derived for location $48^{\circ} \mathrm{N}, 125^{\circ} \mathrm{W}$

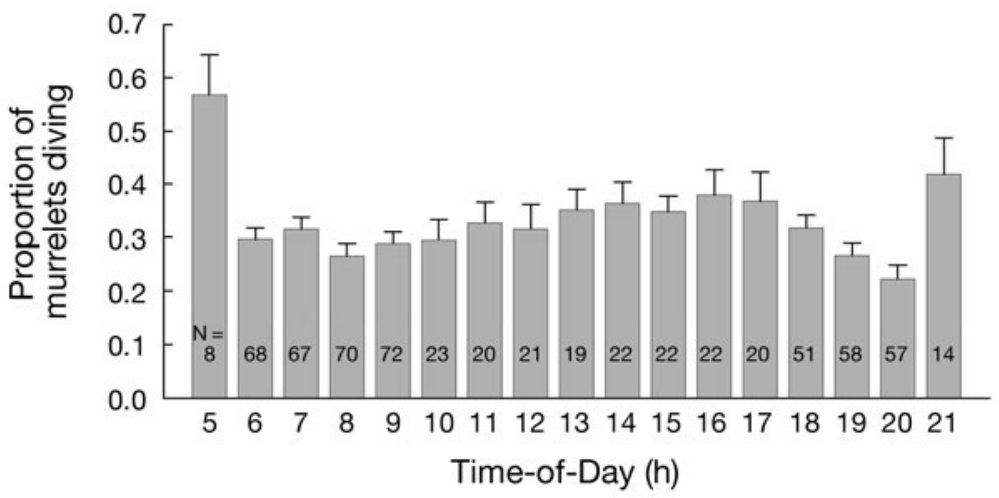

Fig. 3. Brachyramphus marmoratus. Diel patterns in foraging activity. Mean \pm SE proportions of murrelets diving are given for each hour (sample size in bars). Data include all years and sites combined 
Table 3. Brachyramphus marmoratus. Candidate models of temporal, spatial, environmental, and inter- and intra-specific factors affecting foraging activity. Factors included Year, Breeding Phase (Phase), Time-of-Day (TimeDay), Site, Marbled Murrelet density (MM_dens), Common Murre density (CM_dens), Tide phase (Tide), Sea State (SS) and Cloud Cover (CC). k: parameter count; $\mathrm{QAIC}_{\mathrm{c}}$ : quasi-likelihood adjusted Akaike's information criteria; $W_{\mathrm{i}}$ : weight. ${ }^{*}$ denotes interaction terms. $\mathrm{N}=481$ for all models

\begin{tabular}{|c|c|c|c|c|c|}
\hline Model type & Factors included in model & Log-likelihood & $k$ & $\Delta \mathrm{QAIC}_{\mathrm{c}}$ & $\mathrm{QAIC}_{\mathrm{c}} w_{\mathrm{i}}$ \\
\hline Temporal & Year & -436.92 & 4 & 0.00 & 0.40 \\
\hline Temporal & Year*Phase & -431.02 & 6 & 1.38 & 0.20 \\
\hline Temporal & Year*TimeDay & -435.26 & 6 & 3.33 & 0.08 \\
\hline Temporal & Year + Phase & -435.98 & 6 & 3.66 & 0.06 \\
\hline Temporal & Time + Year & -436.82 & 6 & 4.05 & 0.05 \\
\hline Spatial & Site (as a random effect) & -450.28 & 3 & 4.11 & 0.05 \\
\hline Temporal & Year*Phase + TimeDay & -430.75 & 8 & 5.38 & 0.03 \\
\hline Temporal & Year + Year $^{*}$ Phase & -431.02 & 8 & 5.51 & 0.03 \\
\hline Temporal & Phase + Year ${ }^{*}$ Phase & -431.02 & 8 & 5.51 & 0.03 \\
\hline Temporal & Phase*TimeDay + Year & -433.85 & 8 & 6.81 & 0.01 \\
\hline Temporal & Year*TimeDay + Phase*TimeDay & -434.37 & 8 & 7.05 & 0.01 \\
\hline Temporal & Year + Year*TimeDay & -435.26 & 8 & 7.46 & 0.01 \\
\hline Temporal & TimeDay + Year*TimeDay & -435.26 & 8 & 7.46 & 0.01 \\
\hline Temporal & Year + Phase + TimeDay & -435.83 & 8 & 7.72 & 0.01 \\
\hline Environmental & $\mathrm{CC}$ & -458.13 & 3 & 7.73 & 0.01 \\
\hline Temporal & Year ${ }^{*}$ Phase + Phase ${ }^{*}$ TimeDay & -428.60 & 10 & 8.55 & 0.01 \\
\hline Temporal & Year ${ }^{*}$ Phase + Year* TimeDay & -429.56 & 10 & 9.00 & 0.00 \\
\hline Environmental & Tide $+\mathrm{CC}$ & -449.26 & 6 & 9.77 & 0.00 \\
\hline Null & Intercept only & -467.63 & 2 & 10.08 & 0.00 \\
\hline Global & All factors and interactions & -402.31 & 35 & 51.65 & 0.00 \\
\hline \multicolumn{6}{|c|}{$\begin{array}{l}\text { List of candidate models with } \mathbf{A I C}_{\mathbf{c}}>\mathbf{1 0} \\
\text { Temporal [Year*TimeDay + Phase*TimeDay], [Phase], [TimeDay], [Phase*TimeDay], [TimeDay + Phase], } \\
\text { [Phase + Phase*TimeDay], [TimeDay + Phase*TimeDay], [Year*Phase + Phase*TimeDay + Year*TimeDay }] \\
\text { Inter- and intraspecifics[CM_dens], [MM_dens], [CM_dens + MM_dens], [MM_dens*CM_dens] } \\
\text { Environmental[Tide], [SS + CC], [SS], [Tide + SS + CC], [Tide + SS] }\end{array}$} \\
\hline
\end{tabular}

and Green's index of dispersion $\left(\mathrm{r}^{2}=0.627, \mathrm{~N}=12, \mathrm{p}=\right.$ 0.002; Fig. 5f). In all regressions, linear models showed a better fit than logarithmic or quadratic functions.

\section{Indices of annual reproductive success}

Comparing densities of murrelets in adult plumage (AHY birds) and juveniles (HY birds), there were striking differences among years (Fig. 6a,b). AHY birds were more abundant in 2004 than other years. HY birds were most abundant in 2004 and 2006. HY density and HY:AHY ratios provide indices of murrelet reproductive success (Kuletz \& Kendall 1998), and both suggest that 2006 was the best year for raising chicks, 2004 was nearly as good, but 2005 was extremely poor (Fig. 6c). These results, along with those above, suggest that although murrelets increased their foraging effort (Fig. 4) to buffer against low prey availability in early 2005, they were still unable to successfully raise chicks.

Table 4. Brachyramphus marmoratus. Interactions between temporal factors and other factors affecting foraging activity. The temporal factors were selected from Table 3 and based on the parameters with the highest parameter likelihoods (Year, sum $w_{i}$ : 0.56 and Year*Phase, sum $w_{i}$ : 0.28). The temporal model (Year + Year ${ }^{*}$ Phase) was improved with the addition of the spatial (Site) parameter. See Table 3 for other abbreviations

\begin{tabular}{|lcccc|}
\hline Factors included in model & Log-likelihood & $k$ & $\Delta$ QAIC $_{\mathrm{c}}$ & $\mathrm{QAIC}_{\text {i }}$ \\
\hline Year + Year*Phase + Site & -413.77 & 9 & 0.00 & 0.84 \\
Year + Year*Phase & -431.02 & 8 & 5.86 & 0.04 \\
Year + Year*Phase + CC & -426.69 & 9 & 5.94 & 0.04 \\
Year + Year*Phase + CM_dens & -428.96 & 9 & 6.99 & 0.03 \\
Year + Year*Phase + MM_dens ${ }^{*}$ CM_dens & -430.32 & 9 & 7.62 & 0.02 \\
Year + Year*Phase + MM_dens & -430.90 & 9 & 10.43 & 0.02 \\
Null (intercept only) & -467.63 & 2 & 10.86 & 0.00 \\
Year + Year*Phase + Tide & -423.71 & 12 & 13.34 & 0.00 \\
Year + Year*Phase + SS & -429.10 & 12 & & \\
\hline
\end{tabular}




\section{DISCUSSION}

\section{Proportion of birds diving}

We show that murrelets are flexible in their activity budgets whereby the average proportion of birds foraging may range from $\sim 0.15$ to $>0.5$ depending on location, time of day, breeding phase, year and prey availability. This range is comparable to the time murrelets spent foraging in other studies: $23.4 \%$ in Oregon (Henkel et al. 2004), 9 to $12 \%$ in California (Peery et al. 2004) and $>40 \%$ in Alaska (Day \& Nigro 2000). Likewise, other alcids show comparable ranges in foraging time (Davoren \& Burger 1999, Litzow \& Piatt 2003).

The present study is based on the assumption that the ratio of birds diving to those not diving is a valid proxy for foraging effort. However, foraging effort may be measured in several other ways, including shifts in foraging location with an associated increase in flight costs, changes in dive parameters (longer and/or deeper dives), or increases in active feeding period (similar frequency of dives but over a longer period of the day). With murrelets, such parameters are more readily measured by tracking individual birds (Jodice \& Collopy 1999, Henkel et al. 2004, Peery et al. 2004) rather than population-level assessment (the present study, Day \& Nigro 2000). Previous studies have also used proportion of birds diving as a proxy of foraging effort (Day \& Nigro 2000) and 1 tracking study suggested that proportion of time diving was a measure sensitive to food availability (Peery et al. 2004).

Foraging trip duration and discrepancy time at the colony are important individual-level parameters for monitoring predator-prey relationships (Zador \& Piatt 1999, Piatt et al. 2007). Our study was limited to population-level assessment of foraging effort; thus, we acknowledge that other individual-level proxies of foraging effort may have provided additional insight into murrelet-prey relationships. Nevertheless, because murrelets are difficult to capture and nest-based monitoring is not practical, individual-level parameters are typically difficult and expensive to monitor. Thus, the population-level approach used in the present study provides an easily implemented and cost-effective approach for monitoring and management purposes.

\section{Factors influencing diving activity}

Factors influencing diving activity were assessed by comparing competing models in 4 categories: Temporal, Spatial, Environmental, and Inter- and Intraspecific competitors. Overall, temporal and spatial factors had the greatest influence on activity budgets while environmental factors and possible competitors (i.e. murres) had little or no effects.

Breeding phase influenced foraging effort as an interaction term with year; foraging effort increased during incubation and chick-rearing, but only in 2005. Both incubation and chick-rearing are considered energetically expensive periods for birds (Whittow 2002); thus, increased foraging effort during these periods should be expected, especially in 2005, when food supply was low. In other years when prey was abundant early on (2004) and when primary productivity was elevated (2004 and 2006), murrelets showed no increase in diving activity to compensate for energetic demands of incubation or chick-rearing. Time-of-Day was a temporal factor which showed only moderate support in the models tested (Table 3). However, the resolution of this temporal factor was poor (divided into 3 broad Time-ofDay categories), and investigations of hourly diel activ-
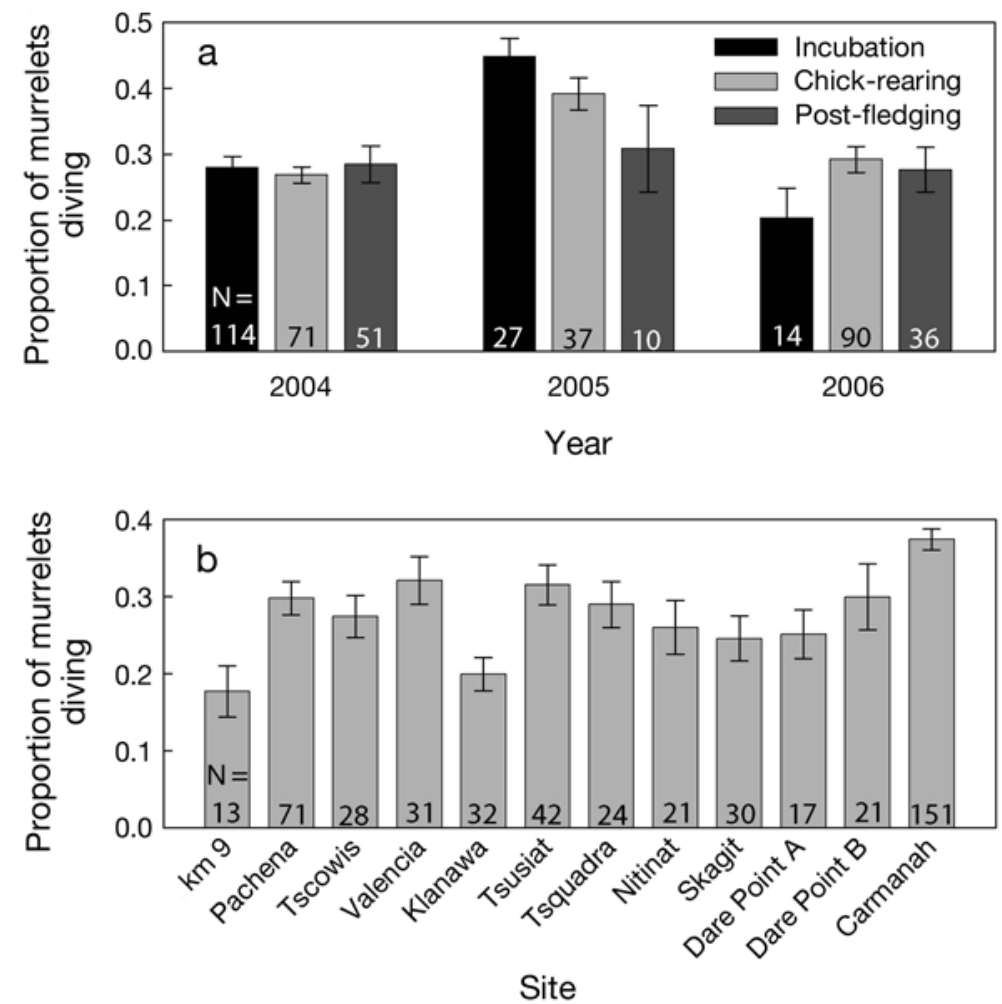

Fig. 4. Brachyramphus marmoratus. Proportions of murrelets diving (mean $\pm \mathrm{SE}$, sample size in bars) (a) across years and breeding phases and (b) among 12 sites. Sites are ordered along the coast from the northwest to the southeast 
ity patterns showed minor variability throughout the day (Fig. 3). Therefore, complex interactions between all temporal factors (Time-of-Day, Phase, and Year) may combine to influence murrelet activity patterns.

Site was also an important predictor of diving activity when modeled with temporal variables and sites with higher prey availability showed decreased foraging activity (Fig. 5d-f). For murres, prey variability among sites influenced colony attendance and chickfeeding rates (Harding et al. 2007). In Alaska, the percentage of murrelets diving differed among habitat types (Day \& Nigro 2000), but this was not linked to prey availability. The significance of a site effect on diving activity in the present study was most likely due to differences in habitat types which may in turn influence prey availability. Visual surveys of fish schools within the study area in 2006 showed that sand lance, a key murrelet prey item, were only found in habitats with sandy or gravel substrates (Haynes et al. 2007). In our study, substrates varied among the 12 survey sites; thus, habitat type may have had a confounding effect on the availability of prey among sites. Future research
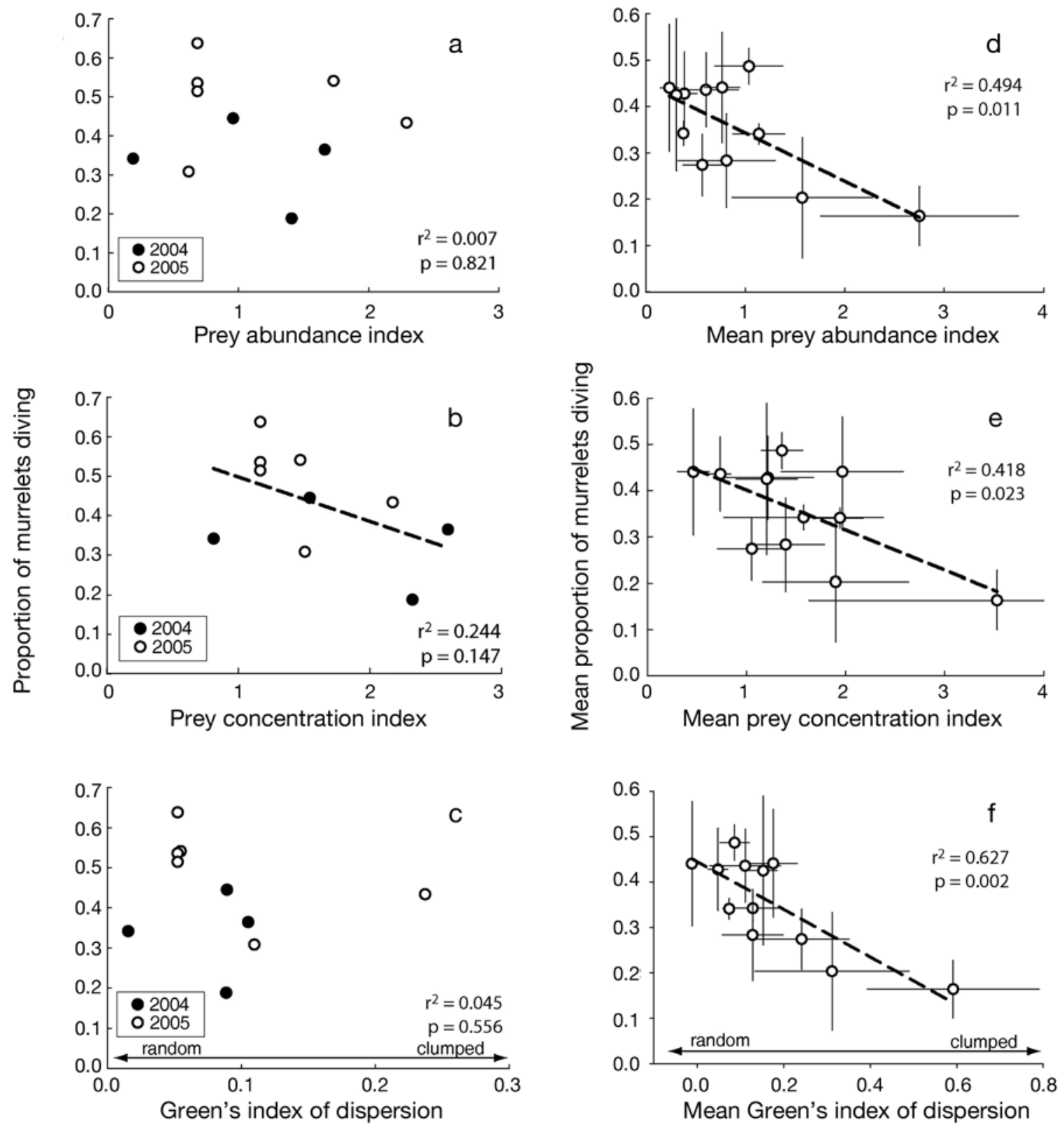

Fig. 5. Brachyramphus marmoratus. Relationships between foraging effort and prey availability. (a-c) Variation among survey dates within 1 site (10 surveys at Carmanah Bay). (d-f) Variation among sites within years (12 sites surveyed in 2005); symbols in $(\mathrm{d}-\mathrm{f})$ represent averaged prey and diving activity estimates for each site (mean $\pm \mathrm{SE}$ ). See Table 2 for definitions of indices 
may seek to quantify murrelet foraging behaviour in relation to specific habitat types.

Environmental variables (Tides, Sea State, CC) had little effect on the foraging activity of murrelets. In Alaska, tides showed no effect on murrelet feeding activity (Day \& Nigro 2000), yet the foraging ecology of other alcids can be influenced by tides (Holm \& Burger 2002). The lack of tidal effects in our study was perhaps because tidal amplitudes are moderate in this region and the study area included open coast with no undersea ridges or narrow passages where tidal effects might be more evident. Murrelets may increase their dive bout duration with increased wave action (Jodice \& Collopy 1999), but sea state effects were not observed in our study.

Surprisingly, there was a lack of apparent influence on diving behaviour by the presence of intra- and inter-specific competitors. Often seabirds use cues of other foraging birds to find suitable foraging locations (Wittenberger \& Hunt 1985). Although murrelets are typically solitary or occur in pairs (Nelson 1997), they also partake in mixed-species feeding flocks. Alternatively, larger alcids may act as competitors for smaller alcids (Piatt 1990, Burger et al. 2008). We saw neither negative nor positive correlations between foraging activity and densities of other murrelets or murres, which might be due to murrelets in this area avoiding close proximity to murres (Burger et al. 2008). Thus, murrelets may forage effectively regardless of local enhancement or potential competitors.

\section{Threshold and timing effects of prey}

Seabirds typically adjust activity budgets with respect to prey availability (Burger \& Piatt 1990, Uttley et al. 1994, Zador \& Piatt 1999), and the present study provides evidence that marbled murrelets do so as well. Murrelets foraged most intensively early in the 2005 season when prey was least abundant and more dispersed. Murrelets also foraged less intensively at sites with more food. The authors of studies of murrelet foraging behaviour in Oregon and California speculated that changes in percentage of time diving was associated with poor prey years (Jodice \& Collopy 1999, Peery et al. 2004), though prey was not quantified.

There was little to no relationship between diving activity and prey availability at one site (Carmanah Bay), yet among sites there was a negative correlation between diving effort and prey availability (Fig. 5). This discrepancy may be explained by the slightly wider range of food availabilities among sites than within Carmanah Bay. Alternatively, this may indicate a hierarchical structure in diving response to prey; murrelets may select among sites to find sites of high
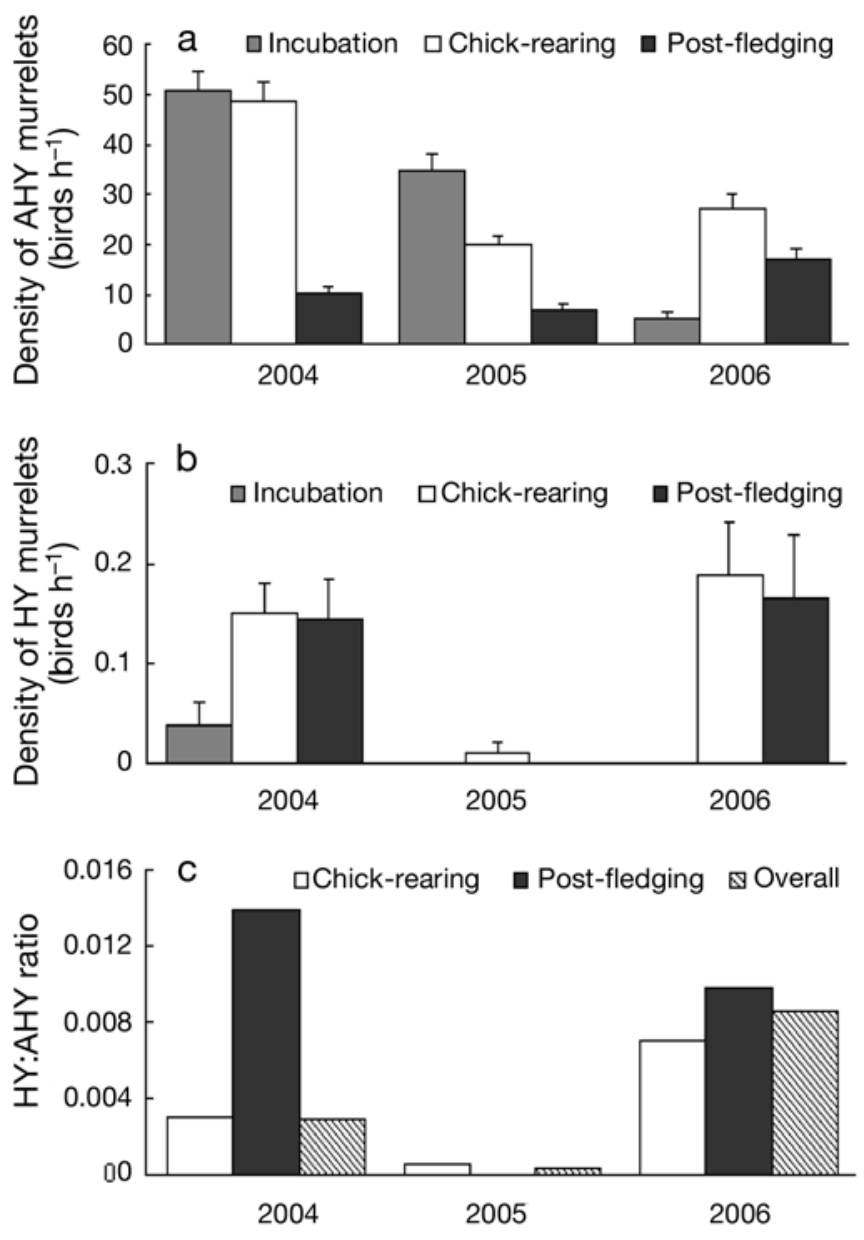

Fig. 6. Brachyramphus marmoratus. Indices of breeding effort, observed by telescope. $(a, b)$ Densities of after-hatchyear (AHY) and hatch-year (HY) birds. (c) Productivity indices (HY:AHY ratio) calculated for chick-rearing and post-fledging periods and also an overall HY:AHY ratio calculated by comparing peak HY densities to peak AHY densities (Kuletz $\&$ Kendall 1998) in each year. Indices are means \pm SE and samples sizes are as follows: incubation $(2004, \mathrm{~N}=131 \mathrm{~h}$; 2005, 62; 2006, 35), chick-rearing $(2004,207$; 2005, 90; 2006, $100)$ and post-fledging $(2004,76 ; 2005,15 ; 2006,48)$. Note $y$-axis scale differs in each panel

prey availability to minimize foraging effort, but within sites changes in prey have little effect on diving effort. Moreover, the only prey index that showed any relationship with diving activity in Carmanah was prey concentration; thus, within sites, prey densities may be more important that overall prey abundance or dispersion. Density thresholds are and important parameter in predator-prey relationships for other seabirds (Piatt 1990).

Organisms may show non-linear responses to changes in prey densities (Holling 1965), suggesting that thresholds in prey densities exist. Marine predators frequently show numerical aggregative responses when prey reach certain density thresholds (Piatt 1990, 
Piatt \& Methven 1992), but may also respond to prey thresholds with behavioural changes (Hines et al. 1997, Piatt et al. 2007). Cairns (1987) predicted a nonlinear relationship between prey availability and predator activity budgets with high foraging effort over low to moderate food supply, but a rapid decline in foraging time with higher food supply. However, linear relationships between murrelet foraging effort and prey suggest no obvious threshold response. Common murres also exhibit linear relationships between foraging trip duration and prey abundance (Piatt et al. 2007). The slope of the response and the presence or absence of a response threshold will likely depend on the range of prey availability observed in any particular study. The linear response observed with murrelets may possibly reflect a limited range in food availabilities during the present study. The inclusion of years and/or sites with higher food ranges may yet identify a threshold response between murrelets and their prey. Nevertheless, responses of marine predators to prey may be complex with both non-linear and linear responses (Reid et al. 2005).

In addition to thresholds, a mismatch in timing between breeding activities and availability of prey can negatively influence seabird reproductive success (Bertram et al. 2001, Suryan et al. 2006). In 2005, delayed coastal upwelling throughout the northeastern Pacific caused a strong mismatch in timing for some seabirds (Sydeman et al. 2006). In our study area, we also saw delayed prey abundance, upwelling indices and primary productivity, similar to patterns further south (Schwing et al. 2006). Moreover, the timing of first fledglings observed in our study area was later in 2005 (12 July) than in 2004 (28 June) or 2006 (26 June). We suspect that the delay in upwelling, associated low primary productivity, and timing of prey availability to murrelets in 2005 had a strong influence on the low reproductive success observed that year.

\section{Buffering ability}

Life-history theory suggests that long-lived organisms such as seabirds invest heavily in rearing few young (Stearns 1992). Many seabirds rear only 1 or 2 chicks $\mathrm{yr}^{-1}$; thus, parental investment tends to be high for most species (Gaston 2004). Adjustment of foraging effort is one way seabirds can successfully rear chicks under variable environmental conditions (Cairns 1987).

If murrelets adjust foraging effort for chick-rearing, then reproductive success could be buffered against years of low prey availability. This was not observed in the present study when, in 2005, murrelets increased their foraging effort but failed to maintain normal levels of reproductive success. Prey availability is thought to be paramount in factors influencing the reproductive success of seabirds (Cairns 1987, Croxall \& Rothery 1991), and murrelet reproductive success has been correlated with prey availability in other regions (Becker et al. 2007). Adjustable time budgets should allow birds to mitigate the effects of scarce prey (Uttley et al. 1994), though some species are simply unable to adjust foraging effort in poor food years (Hennicke \& Culik 2005).

Although murrelets appeared to increase foraging effort when food availability was low, there are several reasons why this may not have been able to maintain reproductive success. First, some alcids readily adjust chick-provisioning rates in response to chick needs (Hipfner et al. 2006), but marbled murrelets may be less able or willing to do so because of adult predation risks associated with nest attendance during daylight (Nelson 1997). Second, prey quality can contribute substantially to the reproductive success or failure of seabirds (Wanless et al. 2005); thus, prey quality effects, not measured in the present study, may also have contributed to low reproductive rates in 2005. Long-term changes in diet quality have been associated with declining murrelet populations and reproductive rates in British Columbia (Norris et al. 2007). An important limitation of the present study was the lack of knowledge of prey species, but other sources of data provide evidence that schooling fish were abundant in 2006. Compared to 2004 and 2005, 2006 was a fairly strong year-class for small herring around Vancouver Island (J. Schweigert pers. comm.). Sand lance were also abundant near beaches in the study area in 2006 (Haynes et al. 2007) though no comparable data are available in other years. Both are important prey species during murrelet nestling and fledgling phases (Burger 2002).

Finally, intensive parental investment can also jeopardize the well-being of the parent (Johnsen et al. 1994), and adults may have been energetically stressed in 2005 when conditions were poor. As such, murrelet life-history strategy likely follows the 'fixed investment hypothesis' (Ricklefs 1987), whereby adults compromise reproductive investment to ensure their own survival when forage conditions are precariously low or not synchronized with breeding activities. Thus, changes in marine prey availability may be a limiting factor to the lifetime reproductive output of this solitary, inland nesting seabird.

Acknowledgements. Many thanks to T. Haynes, N. Hentze, H. Milligan, S. Wong and N. Watson for their excellent field assistance. The Canadian Coast Guard kindly provided accommodation at Carmanah and Pachena Light Stations, 
and we warmly thank lightkeepers J. and J. Etzkorn and S. Bell for all their help there. We thank Parks Canada, and especially B. Hansen and the WCT wardens, for their ongoing collaboration and help. We are extremely grateful to Simon Fraser University (D. Lank) and the Canadian Wildlife Service (D. Bertram) for the loan of a Zodiac. Thanks to K. Allard for advice on modeling and to S. Wong, H. Koopman and several anonymous reviewers for many comments which improved this manuscript. Funding was provided by NSERC Canada (Canada Graduate Scholarship to R.A.R. and Discovery Grant to A.E.B.), Science Horizons Youth Internship Program (Environment Canada), Endangered Species Recovery Fund (World Wildlife Fund and Canadian Wildlife Service), BC Forest Science Program and the Society of Canadian Ornithologists. All procedures were approved by the Animal Care Committee at the University of Victoria and permits were obtained to work in the National Park.

\section{LITERATURE CITED}

Becker BH, Beissinger SR (2006) Centennial decline in the trophic level of an endangered seabird after fisheries decline. Conserv Biol 20:470-479

Becker BH, Peery MZ, Beissinger SR (2007) Ocean climate and prey availability affect the trophic level and reproductive success of the marbled murrelet, an endangered seabird. Mar Ecol Prog Ser 329:267-279

Bertram DF, Mackas DL, McKinnell SM (2001) The seasonal cycle revisited: interannual variation and ecosystem consequences. Prog Oceanogr 49:283-307

Bradley RW, Cooke F, Lougheed LW, Boyd WS (2004) Inferring breeding success through radiotelemetry in the marbled murrelet. J Wildl Manag 68:318-331

Burger AE (1997) Behaviour and numbers of marbled murrelets measured with radar. J Field Ornithol 68:208-223

Burger AE (2002) Conservation assessment of marbled murrelets in British Columbia: a review of the biology, populations, habitat associations and conservation. Canadian Wildlife Service, Pacific and Yukon Region, Delta, BC

Burger AE, Piatt JF (1990) Flexible time budgets in breeding common murres: buffers against variable prey abundance. Stud Avian Biol 14:71-83

Burger AE, Hitchcock CL, Stewart EA, Davoren GK (2008) Coexistence and spatial distributions of marbled murrelets and other alcids off southwest Vancouver Island, British Columbia. Auk 125:192-204

Burnham KP, Anderson DR (2002) Model selection and multimodel inference: a practical information-theoretic approach. Springer-Verlag, New York

Cairns DK (1987) Seabirds as indicators of marine food supplies. Biol Oceanogr 5:261-272

Cam E, Lougheed L, Bradley R, Cooke F (2003) Demographic assessment of a marbled murrelet population from capture-recapture data. Conserv Biol 17:1118-1126

Croxall JP, Rothery P (1991) Population regulation of seabirds: implications of their demography for conservation. In: Perrins CM, Lebreton JD, Hirons GM (eds) Bird population studies: relevance to conservation and management. Oxford University Press, Oxford, p 272-296

Dall SRX, Boyd IL (2002) Provisioning under the risk of starvation. Evol Ecol Res 4:883-896

- Davoren GK, Burger AE (1999) Differences in prey selection and behaviour during self-feeding and chick provisioning in rhinoceros auklets. Anim Behav 58:853-863

Day RH, Nigro DA (2000) Feeding ecology of Kittlitz's and marbled murrelets in Prince William Sound, Alaska. Waterbirds 23:1-14
Gaston AJ (2004) Seabirds: a natural history. T \& AD Poyser, London

Harding AMA, Piatt JF, Schmutz JA, Shultz MT, Van Pelt TI, Kettle AB, Speckman SG (2007) Prey density and the behavioural flexibility of a marine predator: the common murre (Uria aalge). Ecology 88:2024-2033

- Haynes TB, Ronconi RA, Burger AE (2007) Habitat use and behaviour of the Pacific Sand Lance (Ammodytes hexapterus) in the shallow subtidal region of southwestern Vancouver Island. Northwest Naturalist 88:155-167

> Henkel LA, Burkett EE, Takekawa JY (2004) At-sea activity and diving behaviour of a radio-tagged marbled murrelet in central California. Waterbirds 27:9-12

- Hennicke JC, Culik BM (2005) Foraging performance and reproductive success of Humboldt penguins in relation to prey availability. Mar Ecol Prog Ser 296:173-181

Hines AH, Whitlatch RB, Thrush SF, Hewitt JE, Cummings VJ, Dayton PK, Legendre P (1997) Nonlinear foraging response of a large marine predator to benthic prey: eagle ray pits and bivalves in a New Zealand sandflat. J Exp Mar Biol Ecol 216:191-210

Hipfner JM, Gaston AJ, Smith BD (2006) Regulation of provisioning rate in the thick-billed Murre (Uria lomvia). Can J Zool 84:931-938

Holling CS (1965) The functional response of predators to prey density and its role in mimicry and population regulation. Mem Entomol Soc Can 45:1-60

Holm HJ, Burger AE (2002) Foraging behaviour and resource partitioning by diving birds during winter in areas of strong tidal currents. Waterbirds 25:312-325

Jodice PGR, Collopy MW (1999) Diving and foraging patterns of marbled murrelets (Brachyramphus marmoratus): testing predictions from optimal-breathing models. Can J Zool 77:1409-1418

Johnsen I, Erikstad KE, Saether BE (1994) Regulation of parental investment in a long-lived seabird, the puffin Fratercula arctica: an experiment. Oikos 71:273-278

Kuletz KJ, Kendall SJ (1998) A productivity index for marbled murrelets in Alaska based on surveys at sea. J Wildl Manag 62:446-460

> Litzow MA, Piatt JF (2003) Variance in prey abundance influences time budgets of breeding seabirds: evidence from pigeon guillemots Cepphus columba. J Avian Biol 34: $54-64$

Ludwig JA, Reynolds JF (1988) Statistical ecology: a primer on methods and computing. John Wiley \& Sons, New York

McCullagh P, Nelder JA (1989) Generalized linear models. Chapman \& Hall, New York

McFarlane Tranquilla L, Parker NR, Bradley RW, Lank DB, Krebs EA, Lougheed L, Lougheed C (2005) Breeding chronology of marbled murrelets varies between coastal and inshore sites in southern British Columbia. J Field Ornithol 76:357-367

> Mori Y, Boyd IL (2004) The behavioural basis for nonlinear functional responses and optimal foraging in Antarctic fur seals. Ecology 85:398-410

Nelson SK (1997) Marbled murrelet (Brachyramphus marmoratus). In: Poole A, Gill F (eds) The birds of North America, No. 276. Academy of Natural Sciences, Philadelphia, PA, and American Ornithologists' Union, Washington, DC

> Norris DR, Arcese P, Preikshot D, Bertram DF, Kyser TK (2007) Diet reconstruction and historic population dynamics in a threatened seabird. J Appl Ecol 44:875-884

> Peery MZ, Beissinger SR, Newman SH, Burkett EB, Williams TD (2004) Applying the declining population paradigm: diagnosing causes of poor reproduction in the marbled murrelet. Conserv Biol 18:1088-1098 
Peery MZ, Beissinger SR, Burkett E, Newman SH (2006) Local survival of marbled murrelets in central California: roles of oceanographic processes, sex, and radiotagging. J Wildl Manag 70:78-88

Piatt JF (1990) The aggregative response of common murres and Atlantic puffins to schools of capelin. Stud Avian Biol 14:36-51

Piatt JF, Methven DA (1992) Threshold foraging behaviour of baleen whales. Mar Ecol Prog Ser 84:205-210

Piatt JF, Harding AMA, Shultz MT, Speckman SG, van Pelt TI, Drew GS, Kettle AB (2007) Seabirds as indicators of marine food supplies: Cairns revisited. Mar Ecol Prog Ser 352:221-234

Reid K, Croxall JP, Briggs DR, Murphy EJ (2005) Antarctic ecosystem monitoring: quantifying the response of ecosystem indicators to variability in Antarctic krill. ICES J Mar Sci 62:366-373

Ricklefs RE (1987) Response of adult Leach's storm-petrels to increased food demand at the nest. Auk 104:750-756

Schwing FB, Bond NA, Bograd SJ, Mitchell T, Alexander MA, Mantua N (2006) Delayed coastal upwelling along the US West Coast in 2005: a historical perspective. Geophys Res Lett 33:L22S01

Stearns SC (1992) The evolution of life histories. Oxford University Press, Oxford

Suryan RM, Irons DB, Brown ED, Jodice PGR, Roby DD (2006) Site-specific effects on productivity of an upper trophiclevel marine predator: bottom-up, top-down, and mismatch effects on reproduction in a colonial seabird. Prog

Editorial responsibility: Yves Cherel, Villers-en-Bois, France
Oceanogr 68:303-328

Sydeman WJ, Bradley RW, Warzybok P, Abraham CL and others (2006) Planktivorous auklet Ptychoramphus aleuticus responses to ocean climate, 2005: unusual atmospheric blocking? Geophys Res Lett 33:L22S09

Uttley JD, Walton P, Monaghan P, Austin G (1994) The effects of food abundance on breeding performance and adult time budgets of guillemots Uria aalge. Ibis 136: 205-213

Vieira AMC, Hinde JP, Demetrio CGB (2000) Zero-inflated proportion data models applied to a biological control assay. J Appl Stat 27:373-389

> Wanless S, Harris MP, Redman P, Speakman JR (2005) Low energy values of fish as a probable cause of a major seabird breeding failure in the North Sea. Mar Ecol Prog Ser 294:1-8

Waugh SM, Weimerskirch H (2003) Environmental heterogeneity and the evolution of foraging behaviour in long ranging greater albatrosses. Oikos 103:374-384

Whittow GC (2002) Seabird reproductive physiology and energetics. In: Schreiber EA, Burger J (eds) Biology of marine birds. CRC Press, Boca Raton, FL, p 409-437

Wittenberger JF, Hunt GL (1985) The adaptive significance of coloniality in birds. In: Farner DS, King JR, Parkes KC (eds) Avian biology, Vol 8. Academic Press, Toronto, p 1-77

Zador SG, Piatt JF (1999) Time-budgets of common murres at a declining and increasing colony in Alaska. Condor 101:149-152

Submitted: October 4, 2007; Accepted: April 11, 2008 Proofs received from author(s): August 15, 2008 